\title{
Efficient Use of Capital: Paradox of Real Estate and Industry in Turkey
}

\author{
Ali Hepşen ${ }^{1}$, Mehmet Aşıcı ${ }^{2}$ \& Olgun Aydın ${ }^{3}$ \\ ${ }^{1}$ Assoc. Prof. Dr. School of Business, Dept. of Finance, Istanbul University, Istanbul, Turkey \\ ${ }^{2}$ M.Sc., Ministry of Science Industry and Technology, Ankara \\ ${ }^{3}$ PhD. Cand., Inst. of Science, Dept. of Statistics, Mimar Sinan University, Istanbul, Turkey \\ Correspondence: Ali Hepşen, Assoc. Prof. Dr. at School of Business, Dept. of Finance, Istanbul University, \\ Istanbul, Turkey. Tel: 90-212-473-7070. E-mail: alihepsen@yahoo.com
}

Received: June 21, 2017

Accepted: July 17, 2017

Online Published: July 25, 2017

doi:10.5539/ijef.v9n8p221

URL: https://doi.org/10.5539/ijef.v9n8p221

\begin{abstract}
In recent years, one of the hottest debates on Turkish economy is the conflict on resource allocation between real estate and industry sectors. The debate was so intense that ex-minister of Economy Mr. Ali Babacan declared his opinions. Mr. Babacan's statements about the creation of fixed capital by the private sector is not promising, and private sector fixed capital expenditures are not in the desired level. This situation is due to the limited economic growth and future economic growth. In this study, we have investigated whether Mr. Babacan's statement is right or not. We have discussed the reliability of the measurement of real estate output as Gruneberg and Folwell did in 2013 and Ruddock did in 2002. That could be concluded that we agree with ex-minister of Economy Mr. Babacan's comments regarding to imbalances among sectors are threatening Turkish economy's stability. The imbalances are favoring residential real estate investments and consequently the country is exposed to currency risk.
\end{abstract}

Keywords: use of capital, economic development, economic outlook, real estate investments, mortgage issuance

\section{Introduction}

There is evidence of the existence of a very strong relationship between real estate activity and economic growth. As an investment sector, real estate has the potential to impact positively on short-run growth. The real estate sector deals mainly with the provision of capital infrastructure, which has an impact on economic growth over the years in both developed and developing countries. Qifa (2013) stated that the value and growth rate of construction and GDP are highly related, and the situation in China is similar to UK, which is dependent on the nature of construction and its high investment multiplier. Okoye et al. (2016) analyzed the impact of economic fluctuations on the Nigeria real estate sector growth and performance with a view to determining if the growth in the real estate sector is majorly dependent on the patterns of economic performance. They recommended for positive real estate policies as construction sector has the potentials for improving and growing the national economy and recovering economy from recession in Nigeria. Jackman (2010) investigated the relationship between residential construction and economic growth for Barbados. Ramachandra et al. (2013) investigated the direction of the causal relationship between construction and the economy of a developing country, Sri Lanka. Authors concluded and strengthened the body of knowledge on Sri Lanka that the causal relationship between its construction sector and national economy tend towards a uni-directional relationship with the national economy inducing growth in the construction sector and not vice versa. The historical data suggests that there is bi-directional causality between economic growth and residential construction. Kong et al. (2016) studied how real estate investment affects Chinese economic growth. They found that real estate investment has significantly positive contemporaneous effects on economic growth on both national and regional levels by using a dynamic panel data approach to analyze country-level and province-level data in China from 2000 to 2012. Erol and Unal (2015) analyzed the role of construction sector in economic growth in Turkey. They found that expansion in construction sector caused GDP growth over the last five years. The low interest rate environment with the help of radical changes in urban legislation and city building boosted up the construction industry, which resulted in economic growth in subperiod 2010-2014. On the other hand, in recent years, one of the hottest discussions about the Turkish economy has been the conflict in the distribution of resources between the industrial and real estate sectors. The discussions were so 
intense that former Minister of Economy Mr. Ali Babacan expressed his views as following "Fixed capital formation by private sector is not hopeful. Share of private sector's fixed capital expenditure is not at the levels we desire. This phenomenon restrains our recent growth and worries us about the growth in future. There are imbalances among sectors. Lately, particularly the demand in real estate is so high. An economy, without production and undeserving the luxury residential property and luxury consumption which are funded by external debt, might direct Turkey into a dead-end" (online available at www.hurriyet.com.tr).

Even though the problem of allocation of funds between real estate and industrial investments has been discussed after the 2008 financial crisis, it has always been a structural problem of Turkish economy. The problem of concentration of capital in real estate is an adverse effect of the liberal economic policies and urbanization at an enormous pace. The reason we define the problem as an adverse effect is that we do not criticize liberal policies due to an ideological conservatism but we identify the lack of public authority to foresee such adverse effect on time and take necessary measures. The lack of public authority on supervision and control of the real estate market is not unique to Turkey. This deficiency of public authority is observed also in developed countries as 2008 financial crisis indicates.

The increase in international capital flows, because of global financial integration, has been a major factor in supporting the economic growth in many emerging and transition economies, however volatility in capital flows caused fluctuations in central banks' targets such as monetary growth, exchange rate and inflation. Some of the developing countries which prioritized attracting international capital to accelerate their growth have not always been successful and sudden capital outflows resulted in crisis and deep economic recessions (Calvo, 1998). Among the fluctuations Calvo mentioned, monetary growth and inflation are in the scope of our article. Babaoğlu (2005) mentioned 5 main policies used by policy makers to control capital inflows and remove adverse effect of sudden capital outflows. These 5 policies are as follows:

1). Sterilization of capital flows;

2). More flexible exchange rate;

3). Capital controls;

4). Tight fiscal policy;

5). Tightening monetary policy in the case of capital outflow.

\section{Method}

International capital flows resulted in expansion in money supply and, because of money supply, credit expansion occurred. Unfortunately, the policies mentioned above could not prevent cash money leakage into the informal economy which is still at significant levels in Turkish economy. Aşıcı and Hepşen (2013) showed how Turkish housing market benefited from international capital flows and its impact on house price appreciation. Their study is critically important hence Turkish housing market is mainly funded by informal economy and therefore majority of savings are stored in the form of inefficient housing stock.

Mr. Babacan's comment mentioned above is now put into graphics on Figure 1. Fixed capital formation to GDP ratio in Poland, Mexico, India, South Korea and Greece are higher than that of Turkey as seen on Figure 1. Even if India and South Korea are excluded from the comparison due to their sociocultural structure, investment ratio of Turkey is still low and not adequate to sustain the country's desired growth rates. Negative outlook of Turkey as shown on Figure 1 gets worse as shown on Figure 2 on which the savings ratios of economies are shown.

Some of the countries, which have less fixed investment than Turkey as shown on Figure 1, have higher savings ratio than Turkey as shown on Figure 2. Net exports of those countries lead to current account surplus and eventually the savings ratio is higher. The same shift is observed when Turkey and Greece are compared. Due to enormous consumption between 2003 - 2013, Greece failed to have higher saving ratio than Turkey's even though the country had invested significantly higher than Turkey did for the same period. Such a structural problem in the Greek economy, leaded country into the deep economic crisis. 


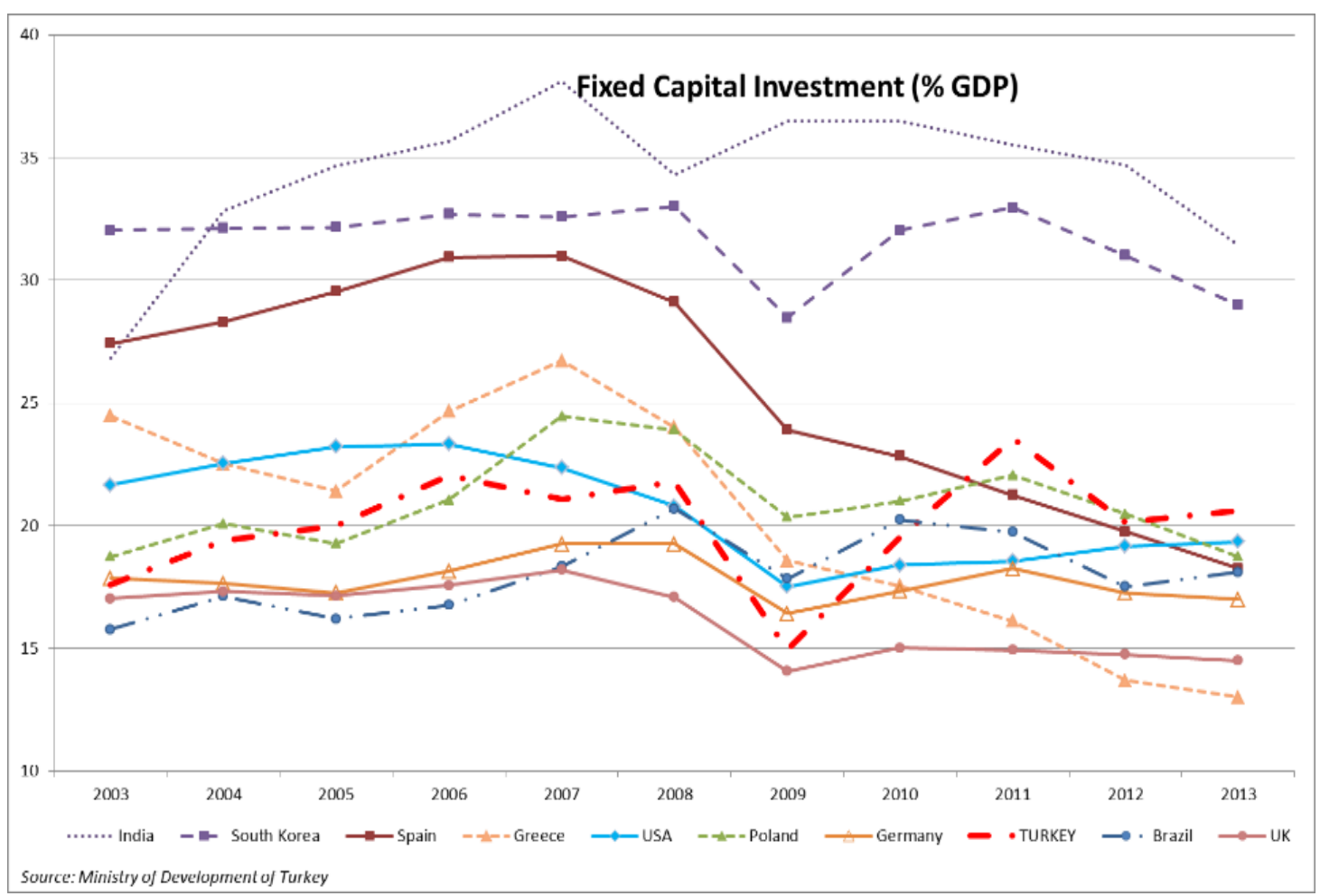

Figure 1. Gross fixed capital investments / GDP

The funding gap between the Figure 1 and 2 is eliminated by external debt. As mentioned above, international capital flows which gained acceleration through liberal economic policies, provided easy access to finance for Turkey and resulted in credit and monetary base expansions. The quality of the investments which are funded by the help of these expansions is extremely important to prevent Turkey from Greece's fate. Turkey's fixed capital investment need which is not quantitatively adequate and it needs to be analyzed qualitatively.

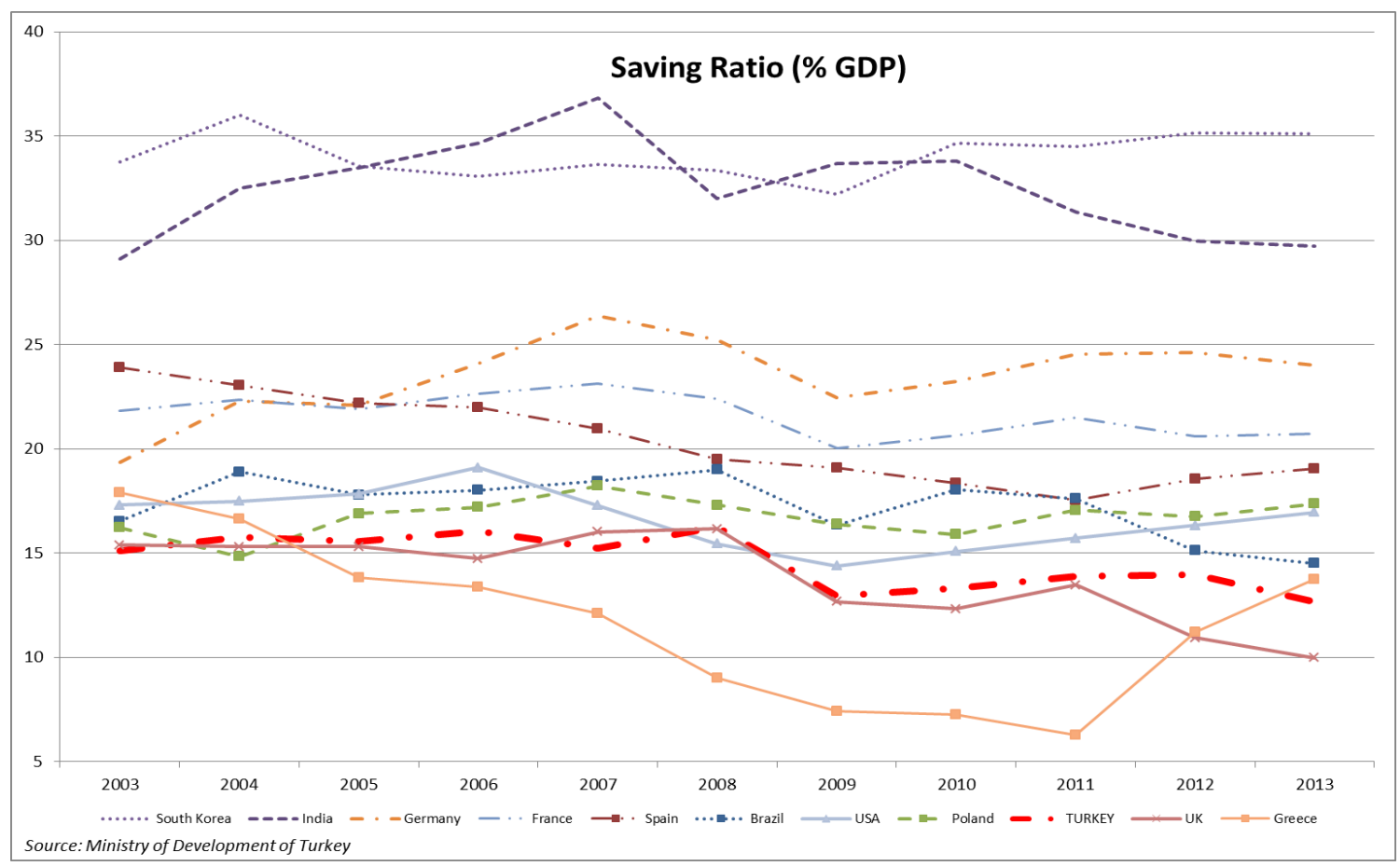

Figure 2. Saving ratio (\% GDP) 
Before starting the analysis, we would like to define quality of investment for the purpose of this paper. The quality of an investment depends on generating sustainable foreign currency revenues in the long run. Based on this definition, the quality of fixed investment decreases as the share of housing increases. Because property investments are domestic products and they cannot generate foreign currency revenues. Figure 3 puts this verbal definition into graphs. As seen on Figure 3, the countries which are net importers have higher rates of housing investment and those countries suffered the most from the global economic crisis which is triggered by sub-prime mortgage crisis in USA.

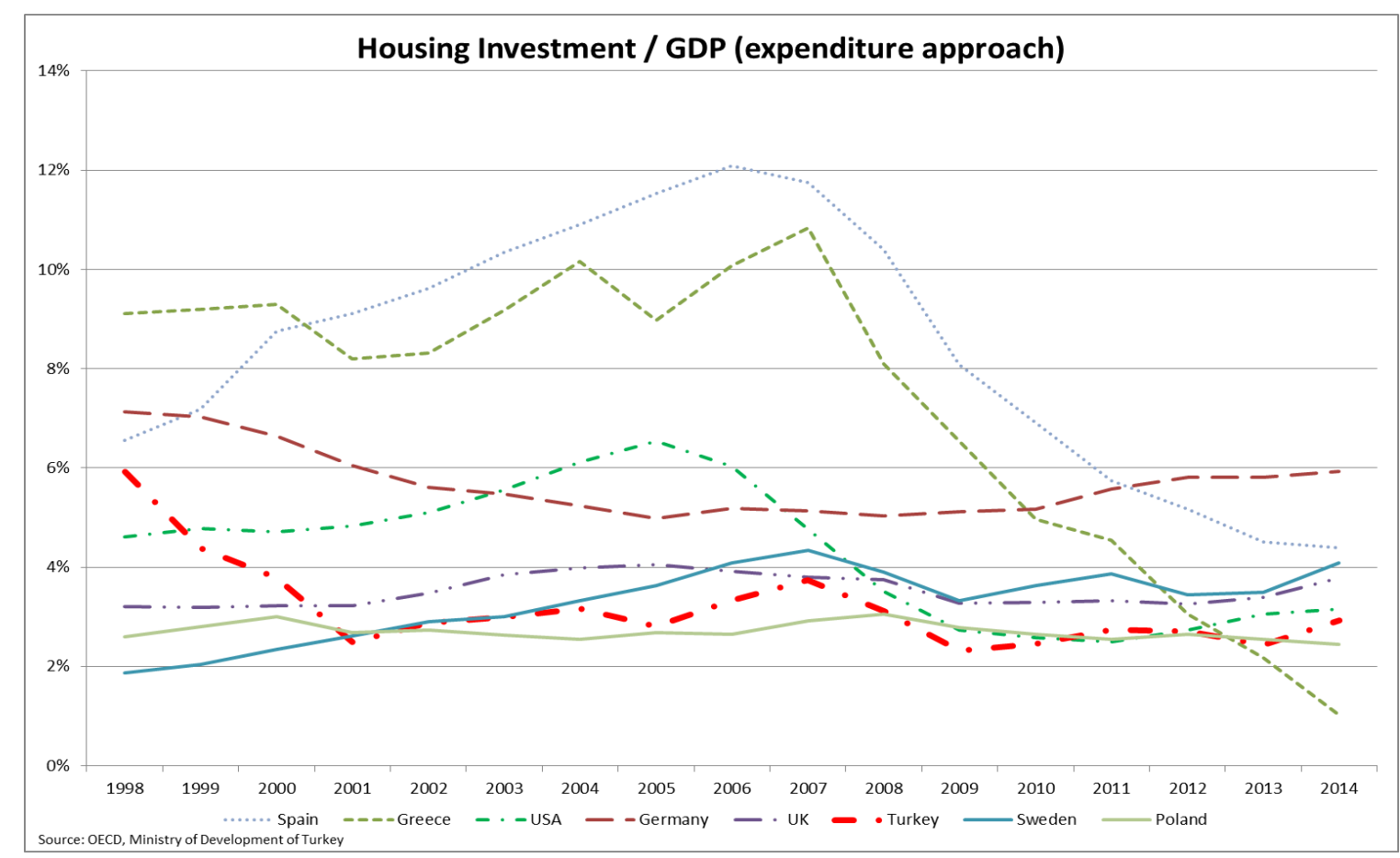

Figure 3. Housing investment / GDP

According to Figure 3, it could be said that Spain and USA needs to be investigated carefully. Spain, thanks to its EU membership in 1986, has reached foreign debt opportunities and accelerated international capital flows. The Mediterranean country, directed a significant amount of these funds into residential investments as seen on Figure 3. It is not surprising that the capital flows into the sector which offers the highest return in the shortest time. Unfortunately, Spanish economic authorities realized only after the 2008 financial crisis that they needed to carefully watch property market. Actually, Spanish property developers responded in advance and the housing investments peaked at $12 \%$ of GDP in 2006, two years prior to the crisis, and decreased to $10 \%$ in 2008 . Unfortunately, Spanish property developers only saved themselves as they decreased their investments while their clients acquired houses at high prices. Property developers continued to decrease their economic activities and in 2014 housing investments accounted for only 4\% of Spanish GDP. It shall be noted that the share of housing investment in Spanish economy might be higher than as we observe on Figure 3 as a result of informal economic activities in construction.

A story similar to Spain's, applies to USA too. The difference between USA and Spain is that American property developers responded well in advance as they were urged strongly by few reliable economists such as Dean Baker. Baker (2002) warned the policy makers 6 years prior to the sub-prime mortgage crisis and he even calculated potential economic losses due to burst of housing bubble in US economy. As a consequence of such warnings, share of housing investment in GDP started to fall in 2005 at its peak of $6.54 \%$ in America. Although, American property developers responded on time, their response was not sufficient to prevent the sub-prime mortgage crisis because the mortgage backed securities (MBS) were already traded in global financial markets. MBS derives their value from the mortgages and the corresponding collateral properties. Because of this value chain, sub-prime mortgage crisis was transferred to global markets.

Graph about Turkey shown on Figure 3 is the most paradoxical one when compared to real economic activity. 
According to the graph, it could be considered that it is paradoxical while the actual housing investments have increased tremendously since 2001, this is not reflected on the graph. This contradictory situation leads us to question the reliability of the official statistics on housing investment.

Informal economy causes the distortion between the official statistics and real economic activity. Politicians and economists agree that informal economy is one of the most important structural problems of Turkish economy. The problem is so severe that Ministry of Finance prepared an Action Plan of Campaign Against Informal Economy Strategy and keeps public opinion informed about the action plan via the web site: http://www.kayitliekonomiyegecis.gov.tr/ The visitors of the website are requested to answer the question "Which sector do they think has the most informal economic activities". As of December 2015, 42\% of respondents think that construction sector has the most informal economic activities. This questionnaire also supports our view that official statistics cannot capture the real conditions of the economy.

\section{Results}

In the following part of the article, mortgage data has been used to verify our view. The data provides an analysis since 2002 because the outstanding mortgage is virtually zero prior to 2002 in Turkey. This is a result of unfavorable economic conditions such as high inflation in the country prior to 2002. As of December 2014, outstanding mortgage amount is 40 billion USD and accounts for 7\% of GDP.

According to TurkSTAT data, $30 \%$ of home sales are funded by mortgage. Considering the maximum loan to value (LTV) ratio is $75 \%$ in Turkey, housing investment supposed to be multiples of mortgage issuance. Based on the LTV and ratio of mortgage sales, housing investment should be at least three times higher than the amount of mortgage issued. Unfortunately Figure 4 shows us contradictory situation.

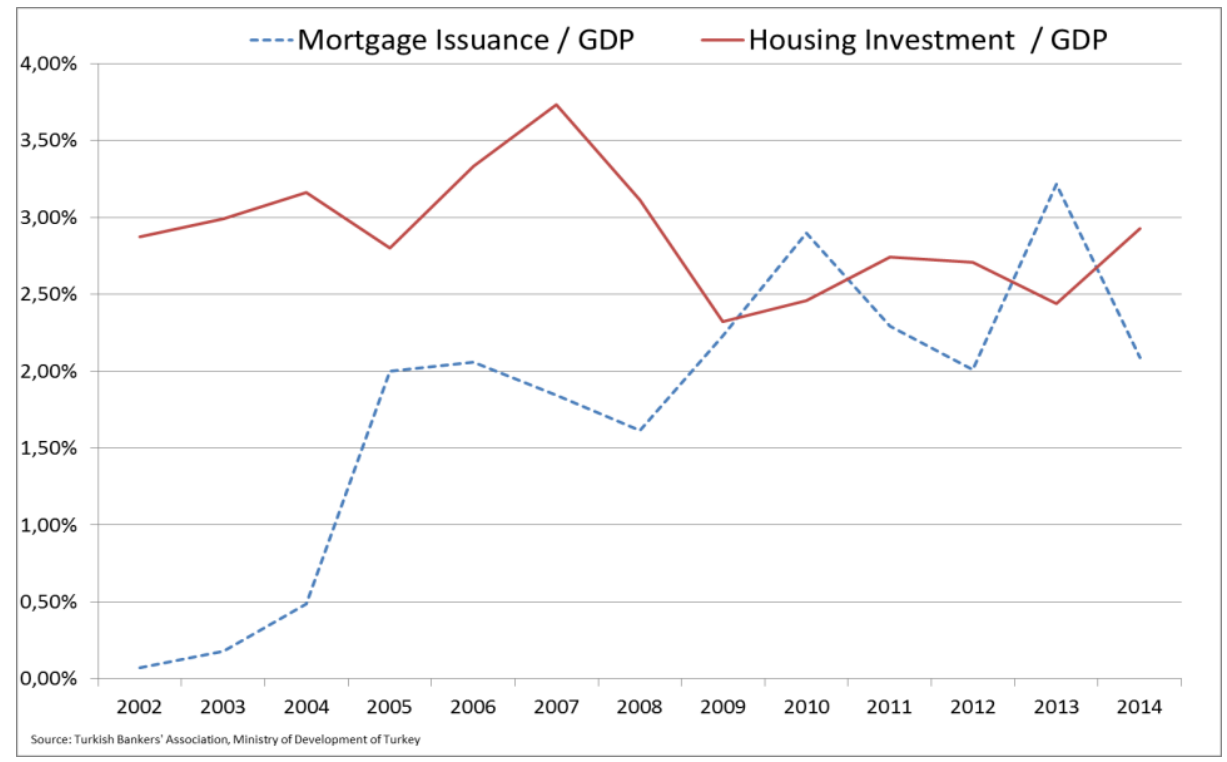

Figure 4. Housing investment - mortgage issuance (Turkey)

Between the years 2002-2008, the relation between the mortgage and housing investment is in the form as we described above. Unfortunately, this 6 years period cannot be used for analysis hence mortgage market was under development with an initial outstanding mortgage to GDP ratio of $0.1 \%$ in 2002 . Therefore, it is not surprising to see that housing investment is multiples of mortgage during this initial period. Due to informal economic activities in construction, we suppose that housing investment is much higher than shown on Figure 4 and other country examples confirm our view on Figure 5.

After 2008, housing investment and mortgage issuance are almost identical and this is a proof of our claim that official statistics do not reflect the actual housing investment. Figure 4 shows that housing investment is funded by mortgage after 2008 while only $30 \%$ of home sales are funded by mortgage. This indicates that the remaining $70 \%$ of home sales are missing. This is a result of informal economic activities. Because, informal economy is not reflected in official statistics. Based on this information, we suppose that actual housing investment to GDP ratio is minimum around $4 \%$ in Turkey as of 2014. 
One of the critics about our comments related to Figure 4 could be that housing investment is a multi-annual process and official statistics only measure the corresponding one-year portion of that for each year. An example would be helpful in explaining the potential critic. Assume that a housing investment started in 2010 and created a value of 50 then the investment completed in 2011 and created another value of 50. The housing investment was put on sale in 2011 and sold in 2012. Official statistics would reflect the transactions as housing investments of 50 in 2010 and 2011 while the sale of the housing investment would be reflected in mortgage statistics only in 2012. For this reason, we can criticize our mortgage lending and housing investment comparisons, but only if this criticism is made for a one-year period. Figure 4 is constructed on data over a 12-year period. In such a long period, property developers should respond to demand and adjust their production as it is the case for Spain and USA shown in Figure 3. This suggests that there must be a convergence and correlation between the housing investment and mortgage issuance.

Another critic about Figure 4, specific to Turkey, could be that a significant portion of houses are sold from the existing housing stock which was produced within last few years. Due to fast house price valuation in Turkey, housing investment recorded in previous years' prices cannot be compared to the sales prices. This could be a valid argument but still does not violate our view that housing investment must be at least twice the size of mortgage issuance. In order to give a clearer answer on this criticism specific to Turkey, TURKSTAT needs to publish the number of empty dwellings. TURKSTAT is able to monitor total number of dwellings, number of people in dwellings and of course check whether the dwelling is empty or not at any time. Our comments about Figure 4 could be verified based on such data. But unfortunately, TurkSTAT refuses to share the data with researchers. The mismatch between housing investment and mortgage issuance becomes obvious as shown on Figure 5 as we are providing an international comparison.

European Mortgage Federation (EMF), Ministry of Development and OECD datasets are used to construct Figure 5. Housing investment data is obtained from dwelling account which is a sub account of GDP by expenditure approach. The data is available on OECD database. Germany, France and Spain provide an account for their gross fixed capital formation and under this account these countries have two sub accounts for construction which are;

- P51N1111: Dwellings

- P51N1112: Other buildings and structures

These two sub accounts show the construction portion of fixed capital formation. Unfortunately, OECD data do not provide such detail for Turkey and the country has only P51N1111: Dwellings account which includes not only dwellings but also other buildings and structures. Therefore, the dwelling sub account for Turkey is obtained from Ministry of Development's database.

As seen on Figure 5, there is a high degree of correlation between housing investment and mortgage issuance in Germany, France and Spain. On the other hand, such a relation is not observed for Turkey. The correlation, observed for Germany France and Spain, is confirming our comments about Figure 3 and 4. This is a concrete proof of informal economic activities in Turkish construction sector and also confirms that official statistics of housing investment are not reliable.

The problem of unreliable measurement of housing investment leads us to the social problem of measurement error of income inequality. Not only housing investment is measured lower than the actual but also income inequality. Performers of informal economic activities are hiding their wealth in the form of real estate and thus leading to increase home prices and eventually decrease housing affordability dramatically for the middle and low-income households. As a consequence of these measurement errors, the policy makers are not able to notice that there is a need to increase transfer payments to middle and low-income households. In this respect, Aşıc1, Hepşen and Yilmaz (2011) constructed the Housing Affordability Index (HAI) of Turkey and showed that for each income group a separate HAI needs to be calculated to have clearer picture of income inequality. Neither in Turkey nor in any other countries, due to lack of sufficient data, HAI could not be calculated for different income groups. Unfortunately, the conventional measures of housing affordability hides the disadvantages of the middle and low-income groups because such measures are all based on average or median income and house prices. 

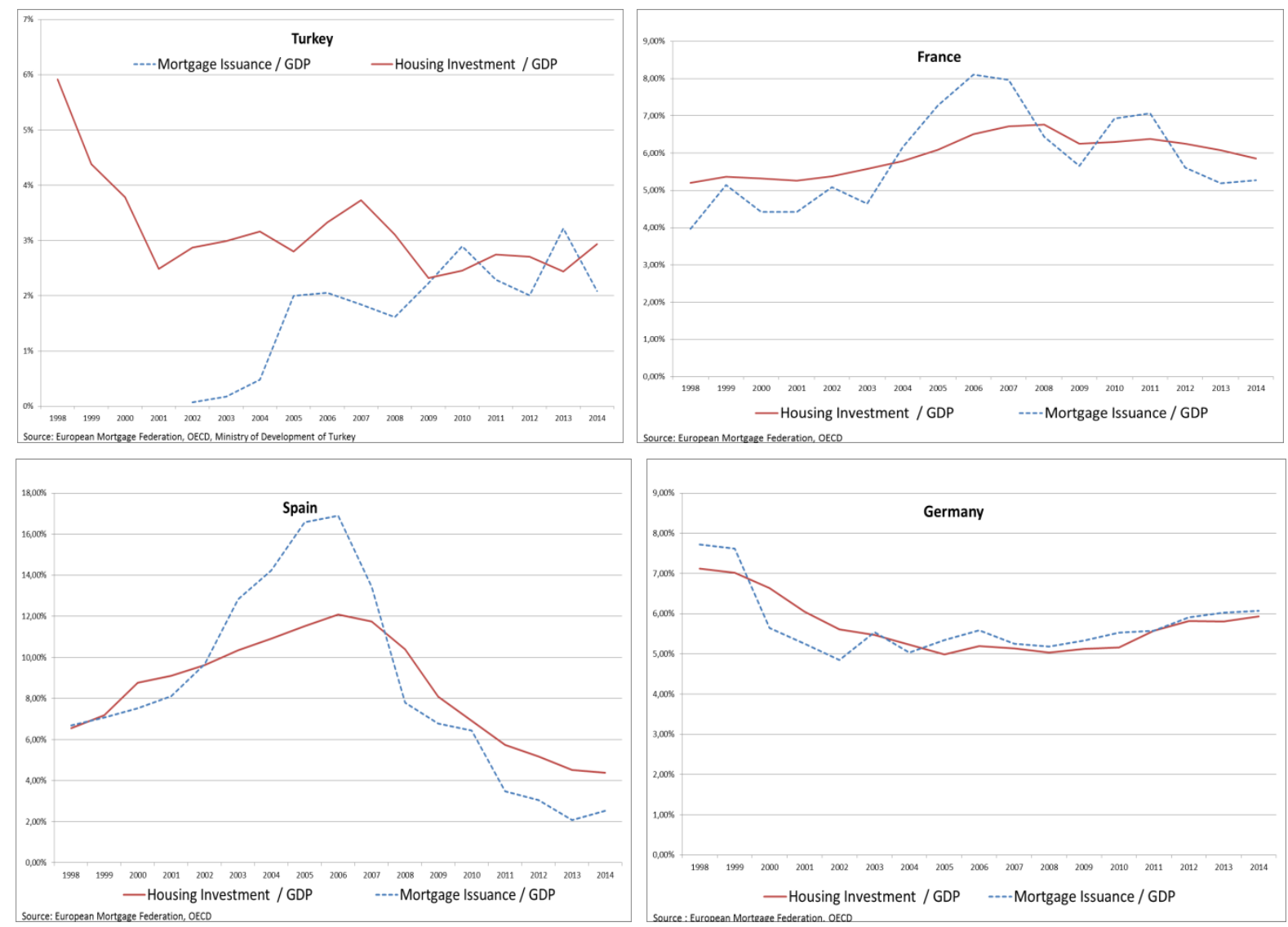

Figure 5. Housing investment - Mortgage issuance

\section{Discussion}

Real estate sector, serving as an important sector of national economy, has played an important role in economic growth. The real estate sector encourages economic growth in large quantities and outputs, which appear to be fairly high through inter-sectoral links between real estate and other sectors. In that sense, we can conclude that we agree with ex-minister of Economy Mr. Babacan's comments regarding to imbalances among sectors about threatening Turkish economy's stability. The imbalances are favoring residential real estate investments and consequently the country is exposed to currency risk. The currency risk is so severe that the country might experience a similar crisis of balance of payments as in 1994 and 2001 following a deceleration in international capital flows. Turkish economic authorities need to proactively respond to potential risks. To be proactive, the authorities must be able to investigate the actual economic indicators. One of these indicators is the share of housing investment and currently the official statistics are not able to reflect its real size. In order to use the capital more efficiently and reduce the currency risk, we suggest that Turkish economic authorities should discourage residential real estate investment, i.e. introduce additional tax burdens. It is also obvious that there is a need for a tool which precisely measures the housing investments in Turkey. The precision of this tool can be verified by comparing the housing investment with mortgage issuance as in Figure 4.

\section{References}

Aşıc1, M., Hepşen, A., \& Yılmaz, Ö. (2011). Housing Affordability Index Calculation Integrating Income Inequality in Turkey. Empirical Economics Letters, 10(4), 359-367

Babaoğlu, D. (2005). Administration of Capital Flows: Evaluation of Turkey. Expertise Proficiency Thesis, Central Bank of The Republic of Turkey, Ankara.

Baker, D. (2002). The run-up in home prices: A bubble. Challenge, 45(6), 93-119. http://dx.doi.org/10.1080/05775132.2002.11034180

Calvo, G. A. (1998). Capital Flows and Capital Market Crises, The Simple Economics of Sudden Stop. Journal of Applied Economics, 1(1), 35-54. 
Erol, I., \& Unal, U. (2015). Role of Construction Sector in Economic Growth: New Evidence from Turkey. Munich Personal RePEc Archive, MPRA Paper No. 68263.

Gruneberg, S., \& Folwell, K. (2013). The use of gross fixed capital formation as a measure of construction $\begin{array}{llll}\text { output. Construction Management and } & \text { Economics, 31(4), 369-368. }\end{array}$ http://dx.doi.org/10.1080/01446193.2013.790555

Hepsen, A., \& Asici, M. (2013). The Association between Current Account Deficit and House Prices in Turkey. Journal of Applied Finance \& Banking, 3(3), 65-79.

Jackman, M. (2010). Investigating the Relationship between Residential Construction and Economic Growth in a Small Developing Country: The Case of Barbados. International Real Estate Review, 13(1), 109-116.

Kong, Y. et al. (2016). An Investigation into Real Estate Investment and Economic Growth in China: A Dynamic Panel Data Approach. Sustainability, 8(1), 66. http://dx.doi.org/10.3390/su8010066

Newspaper, H. (2014). Retrieved from http://www.hurriyet.com.tr/sanayiden-kacip-konut-yapiyoruz-26874076

Okoye, P. U. et al. (2016). Imperatives of Economic Fluctuations in the Growth and Performance of Nigeria Construction Sector. Microeconomics and Macroeconomics, 4(2), 46-55. http://dx.doi.org/10.5923/j.m2economics.20160402.02

Qifa, J. (2013). Analysis on the Relationship between GDP and Construction Based on the Data of UK and China. Conference Paper, International Conference on Education Technology and Management Science.

Ramachandra, T. et al. (2013). Direction of causal relationship between construction and the national economy of Sri Lanka. Journal of Construction in Developing Countries, 18(2), 49-63.

Ruddock, L. (2002). Measuring the global construction industry: Improving the quality of data. Construction Management \& Economics, 20(7), 553-556. http://dx.doi.org/10.1080/01446190210159908

\section{Copyrights}

Copyright for this article is retained by the author(s), with first publication rights granted to the journal.

This is an open-access article distributed under the terms and conditions of the Creative Commons Attribution license (http://creativecommons.org/licenses/by/4.0/). 